Regards sur l'économie allemande

Bulletin économique du CIRAC

116-117| 2015

Varia

\title{
Elections au Bundestag
}

KORTE Karl-Rudolf (Hrsg.), Die Bundestagswahl 2013 - Analysen der Wahl-, Parteien-, Kommunikations- und Regierungsforschung

\section{(2) OpenEdition}

\section{Journals}

Édition électronique

URL : http://journals.openedition.org/rea/4840

DOI : $10.4000 /$ rea.4840

ISSN : 1965-0787

Éditeur

CIRAC

Édition imprimée

Date de publication : 1 juillet 2015

Pagination : 75

ISSN : 1156-8992

Référence électronique

"Elections au Bundestag », Regards sur l'économie allemande [En ligne], 116-117 | juillet 2015, mis en ligne le 01 juillet 2015, consulté le 22 septembre 2020. URL : http://journals.openedition.org/rea/4840 ; DOl : https://doi.org/10.4000/rea.4840

Ce document a été généré automatiquement le 22 septembre 2020

(C) CIRAC 


\section{Elections au Bundestag}

KORTE Karl-Rudolf (Hrsg.), Die Bundestagswahl 2013 - Analysen der Wahl-, Parteien-, Kommunikations- und Regierungsforschung

\section{RÉFÉRENCE}

KORTE Karl-Rudolf (Hrsg.), Die Bundestagswahl 2013 - Analysen der Wahl-, Parteien-, Kommunikations- und Regierungsforschung, Springer VS, Wiesbaden, $2015,540 \mathrm{p}$.

1 Quelle influence ont eue programmes et personnalités politiques sur la campagne et les résultats des élections au Bundestag de 2013 ? Et avec quelles conséquences sur la façon de diriger le pays? Politistes, sociologues, chercheurs en communication et responsables politiques abordent ces questions sous quatre angles: recherche électorale, recherche sur les partis, recherche en communication et recherche sur la gouvernance. (Solène Hazouard) 